\title{
La pasión por el exilio: Pensando la teología de la liberación entre la soledad y la solidaridad Passion for Exile: Thinking
} Liberation Theology Between Solitude and Solidarity
A paixão pelo exílio: Pensando na teologia da libertação entre a solidão e a solidariedade

\section{An Yountae \\ Recibido: 06 de marzo 2017 \\ Aprobado: 15 de mayo 2017}

"For exile did not arise yesterday: it began with the departure of the first caravel.

It is not a state, but a passion». Edouard Glissant

Over the past century, there has been a fascination with the trope of exile within the intellectual and artist community. The unique experience that exile provides - distance, liminality, ambivalence, cross-cultural/linguistic perspective - has served, in a way, as an important source for profound intellectual and artistic inspiration in many places of the world. It is in this sense that George Steiner suggests that the whole genre of twentieth 


\section{SIWÔ ${ }^{\text {volumen 10, Nimerers 1, 2016 }}$}

century Western literature is "extraterritorial," that is, "a literature by and about exiles". ${ }^{1}$

Similarly, exile has played a central role in shaping the contours of the Caribbean literature and philosophy as the historical reality of (neo)colonialism renders the experience of exile a constitutive element of life in the Antilles. As Jan Carew writes, "the Caribbean writer today is a creature balanced between limbo and nothingness, exile abroad and homelessness." ${ }^{2}$ This is because the identity of the Caribbean individual is comprised of multiple cultural/historical fragments -Amerindian, African, European, Asian- but more so because the history of exile in the Antilles is characterized by "ethnocide, slavery, indentured labor, racism, colonialism, and more recently, neocolonialism."”

It is then no strange that in most cases the works of the authors in exile are directed at searching for a redemptive quality out of the experience of displacement and alienation. However, the creative endeavor of transforming pain into possibility always entails the risk of romanticizing the devastating reality of loss and suffering. Perhaps, one needs to take Edward Said's advice seriously and not forget that "the achievements of exile are permanently undermined by the loss of something left behind forever." ${ }^{\prime 4}$ The trope of exile becomes an even more complicated question when considering the global reality of refugees and migrant workers for whom the experience of displacement keeps determining the conditions of their economic or material survival. Should we, then, refuse to affirm the experience of exile as a signifier of hope for a reconciled self and homecoming?

1 Edward W. Said, Reflections on Exiles and Other Essay (Cambridge: Harvard University Press, 2002), 174.

2 Jan Carew, "The Caribbean Writer and Exile," Journal of Black Studies, Vol 8, No 4 (Jun 1978), 453.

3 Ibid., 460

4 Said, 174. 
Despite the possible dangers harboring in its linguistic practice, there still seems to be a strong need to redeem the trope of exile as a positive ground for envisioning transformation as long as exile keeps conditioning the lives of many people around the globe today. Said too, affirms - despite his vigilant warning -- the potential implied in the trope of exile as it asks us to cultivate a critical consciousness, namely, a "scrupulous subjectivity." How, then, shall we re-envision or reconstruct the trope of exile in ways that allow us to insist on its use -- by retaining or exploring the gift of creativity that exile provides -- without conflating its poetic or creative potential with the historical reality of people living under the condition of exile? More importantly, what are the challenges and insights that the trope of exile provides for thinking ethics, liberation, and counter-colonial movement in the era of capitalist globalization and trans-spatiality?

It is questionable whether contemporary scholarship's fascination with exile has been successfully followed up with its development into a liberationist discourse. It seems that the notion of exile, marked with solitude and self-reflection, often tends to fall into a self-absorbed form of individual practice, a perpetuating withdrawal towards the inner-self. The problem, I argue, lies in that it often fails to foster a concrete vision of transformation of both the self and, most importantly, the community. The difficulty of translating the spiritual profundity of solitude and self reflection implicated in exile into a discourse of liberation for the community results in the limited linguistic practice of exile as an intellectual and poetic errantry.

Keeping this difficulty in mind, in this essay I take up the Jewish liberation theologian Marc Ellis' idea of "practicing exile" and explore the idea of exile as the ground for rethinking liberation theology. Ellis's suggestion of practicing exile "as a way

5 Ibid., 184. 


\section{SIWÔ ${ }_{\text {volumen 10, Nimerers 1, } 2016}$}

of walking away and toward," in the "profoundest solitude and solidarity," finds a creative resonance with the French Martinican thinker Edouad Glissant's ideas. ${ }^{6}$ As a thinker of diaspora, the trajectory of Glissant's thought is marked with a ceaseless tension between rootedness and errantry, pain and beauty, solitude and relation.

This essay explores the political possibilities lurking in the trope of exile as suggested by Glissant. My reading aims at articulating the notion of exile as the possible womb for developing a liberation theology at the complex intersection of (neo) colonial violence, trauma, political economy, spirituality, and counter-colonial discourse within the context of Latin America.

\section{Thinking Exile Between Globalization and Migration}

Exile refers to the state of being uprooted from one's homeland and prevented from going back home. It means living in a constant state of suspension, in a relentless search for roots and ground amidst groundlessness. At the same time, exile also signifies a permanent departure from the past and the old consciousness; life and its meaning carries a different connotation as what seemed to be the normal and familiar becomes elusive, while the unfamiliar begins to constitute the basic conditions of life. This means that along with exile comes the experience of being thrown in the in-between space, between the irrecoverability of what has now become an imagined space, and the precariousness or contradictory reality of "here:" a state of constant oscillation between rootedness and flight.

6 Marc H. Ellis, "Practising Exile: A Refleciton on the Jewish Exile and the New Diaspora," Swedish Missiological Themes, 85, 3-4 (1997), 291. 
As Said remarks, the twentieth century's fascination with exile lurks both its peril and possibility at the same time. Undeniably, the experience or state of exile creates new possibilities by expanding the horizon of the person who is in exile. The constant state of being out of place bears an unending thirst for the search of root. At the same time, she (the person in exile) refuses to settle and easily compromise for the root that she is ardently searching, for she knows that such root, as a signifier of a static origin, fixed to a geographic location, no longer exists. Root becomes a loss. This loss, however, is not conducive to resignation. Rather, loss becomes the driving force behind her vigilance and alertness for what lies concealed, beyond the given.

Such redemptive qualities of exile becomes, however, a complicated question when reflecting from the lived experience of those who inhabit the space of loss, those who have been violently dislocated from their roots and living in search of the impossible. Objecting any attempt to romanticize exile, Said writes, "But to think of the exile informing this literature as beneficially humanistic is to banalize its mutilations, the losses it inflicts on those who suffer them..." This is why, Said goes on to add, "you must therefore map territories of experience beyond those mapped by the literature of exile itself. You must first set aside Joyce and Nabokov and think instead of the uncountable masses for whom UN agencies have been created."

Yet, another important aspect of exile is that it refuses the simple binary of "either or." It points, rather, to a constant slippage, oscillation, or going back and forth between the opposites. In other words, the creative tension or movement structuring the experience of exile exceeds the measure or terms of the negative and the positive, loss and gain, or possibility and impossibility.

7 Ibid., 174.

8 Ibid., 175. 


\section{SIWÔ ’ Volumen 10, Números 1, 2016}

Rather, exile is conditioned by the paradox of being here and elsewhere, remembering and forgetting, to be rooted and in errantry, at one and the same time. The Haitian writer Yanick Lahens illustrates the contradictory or paradoxical movement of exile very well as she writes,

For us it is not a question of exalting elsewhere on pain of total dispossession nor of exacerbating withdrawal on pain of confinement and certain death, but of leaving withdrawal behind without losing oneself in elsewhere. The search for a new center of gravity, for a new point of equilibrium, is certainly one of the major stakes of the moment. ${ }^{9}$

One of the paramount strengths that the trope of exile provides is its reference to the ceaseless, dialectical movement of withdrawal, becoming, and transformation. Instead of designating a definitive and determinate trajectory, exile points to the incessant movement of restlessness, the crossing of the boundaries, by disrupting the gap between the opposites, always in search of a renewed/renewing future. While it is far from difficult to see the potential that such attributes of exile provides for the liberationist thought, it is more than difficult to find many such examples in which the spirit of exile is successfully translated into a solid discourse of transformation and liberation of the community. As I mentioned earlier, many powerful forms of reflection on exile find expression in, mostly poetic and literary practice of errantry, with their focus on the existential negotiation of the individual with his/her inner-split self. As Said pointed out, in some cases, these literary practices conflate the experience of the elite intellectual in exile with the reality of painful displacement and loss experienced by people whose lives are marked outside the map of literary exile. One can see, for instance, in the work of the Haitian poet Rene Depestre that his

9 Yanick Lahens, "Exile: Between Writing and Place," Callaloo, Vol 15, No 3 (Summer, 1992), 737. 
wanderings in Europe and the Caribbean are not depicted as a painful experience of dislocation, "but rather a ubiquitous adaptable self drawing on a cross-cultural reality." ${ }^{10}$ As Michael Dash comments, Depestre's notion of geolibertinage "insists on the positive potential for self-transformation inherent in the conditions of poetic refugee."11

On the other hand, critical accounts of exile point to the new possibilities that the creative convergence of socio-political criticism and the experience of exile produce as a form of powerful tool for change. Said's reflection on exile is one such example in which not only are the differences of social location acknowledged, but also the critical self-reflection emerging from exile fosters a vigilant consciousness for the transformation of the collective, social structure. It is unclear, however, how the terms of existential (or intellectual) solitude articulated through self-reflection is transferred or developed into a form of critical collective consciousness and solidarity. This is because the unyielding refusal to settle and affiliate with a particular community might well lead into a flight towards the inner self via poetic or literary refugee. The question that follows, then, is, how to reinvent a new idiom for exile that does not fall into the narrow terms of the self-absorbed politics of belonging and the concern for self-transformation, but extends to a political vision that addresses the wider global community of the displaced and the disenfranchised? How do we transform the existential terms of solitude and the transformative power of radical self-reflection into the socio-political imagination that re-articulates justice, change, and solidarity?

10 Michael Dash, "Engagement, Errance, and Exile," Callaloo, Vol 15, No 3 (Summer, 1992), 750.

11 Ibid. 


\section{SWWO ${ }^{\text {? }}$ volumen 10, Números 1, 2016}

\section{Liberation Theology After Trauma}

The experience of exile is a crucial marker that shapes the development of early Judeo-Christian canonical literature. Not only does the decisive historical experience that triggers the identity formation of the early Israelites emerge from the period of wandering in the foreign land as strangers, but the majority of the canonical texts were composed during the Persian period, when Jews were living as minority in different parts of Mesopotamia and Egypt. The New Testament, partly inflected by the Platonic dualism, also testifies on exile, viewing it as an important metaphor for describing the status of the believers who were living in between the prevailing eschatological hope and the postponed Parousia. As people not belonging to the world John (15:19), human life in this world is viewed as a state of exile while constantly longing for a better country - a heavenly one Hebreos (11:16).

Meanwhile, exile and dislocation have seldom been at the center of attention in the major writings of Latin American Liberation Theology, an irony when remembering the fact that the history of Latin American cannot be separated from the violent historical events of colonialism, slavery, displacement, appropriation and genocide of the local indigenous population. As many critics have already pointed out since decades ago, one of the major problems of the early Latin American Liberation Theology was its conceptualization of "the poor" as a single, homogenous category. In the early stage of its development, the exclusive association of the poor with politico-economic oppression resulted in the exclusion of a diverse range of experiences that marginalize people, or better, "life" such as (hetero)sexism, racism, and the exploitation of nature. The works of the later generation of scholars such as Ivone Gebara, Elsa Tamez, Luis Rivera-Pagan, and Marcella Althaus-reid, among many others, 
sought to address such problems inherent in the early development of its theological movement.

In his reading of Latin American Liberation Theology from the lens of "colonial difference," Nelson Maldonado-Torres asserts that the Latin American theological movement was a form of articulating the "colonial difference" presupposed in Europe's hegemonic expansion of its political and economic power. Indeed, the adoption of dependency theory as its socio-analytic tool, its critique of the global web of economic appropriation established by Europe, followed by the assertion of a reinvented theological language that challenges the hegemonic practice of knowledge from the periphery indicates the innovative potential that this theological movement suggests for envisioning a counter-colonial critique of the global geopolitics of knowledge and power. However, Maldonado-Torres also points out how liberation theology, in its articulation of colonial difference, "failed to realize the complexity of the coloniality of power, in particular, the situation of colonial heterogeneity." ${ }^{12}$ By this, Maldonado-Torres refers to the structurally heterogeneous colonial space in which colonial difference is born. In other words, colonial difference emerges from a space inherently structured by contradictions and tensions, marking and creating subjectivities in multiple complex ways, so that not only class, but also gender, sex, and race constitute the expression of colonial difference.

Following the tradition of Latin American/Caribbean decolonial thinkers such as Aime Cesaire, Franz Fanon, Enrique Dussel, and Anibal Quijano, Maldonado-Torres analyzes the ontological condition or texture of the colonial subject whose edifice of being is structured by "coloniality." With his comparative

12 Nelson Maldonado-Torres, "Liberation Theology and the Search for the Lost Paradigm: From Radical Orthodoxy to Radical Diversality," in Latin American Liberation Theology: The Next Generation, ed. Ivan Petrella (Maryknoll: Orbis, 2005), 55. 


\section{SIWÔ ${ }_{\text {volumen } 10, \text { Nimerers } 1,2016}$}

reading of Heidegger and Fanon, Maldonado-Torres demonstrates that if it is Da-Sein, the inescapability and singularity of one's own death that conditions the authenticity of existence for Heidegger, for the racialized, death is not an individualized, "extra-ordinary affair, but a constitutive feature of reality. ${ }^{13}$ The vision for decolonial struggle or liberation emerges "not through an encounter with one's own immortality [as it is the case with Heidegger], but from a desire to evade death, one's own but even more fundamentally that of others." 14 Maldonado-Torres's reading shows how racialization and coloniality are two of the most crucial elements that constitute not only the socio-cultural relationships of Latin America and the Caribbean but also the psychic fabric of its people. Following this insight, I contend that a critique of the on-going conditions of coloniality and neocolonialism should be at the center of liberation theology.

Certainly, liberation theology's critique of the modern world economy shares a similar theoretical ground with decolonial thinkers' critique of coloniality or what Quijano calls "the coloniality of power." Common to both groups is the view of the Eurocentric model of capitalist expansion as a form of neocolonialism in which the third world serves as the resource of appropriation and exploitation, under the name of development (in the case of dependency theory/liberation theology) or globalization (decolonial thinking). ${ }^{15}$ Therefore, despite the lack of a rigorous analysis of the race-labor relationship conditioning the colonial structure of Latin American societies, liberation theology's contribution to the critique of coloniality should not be underrated. Nevertheless, the lack of concern for the racial

13 Nelson Maldonado-Torres, "On the Coloniality of Being: Contributions to the Development of a Concept." Cultural Studies Vol 21, Nos. 2-3, (March/May 2007): 251.

14 Ibid.

15 It is important to note that, however, for Quijano, race occupies the central place in his analysis of coloniality of power as race was the main tool used in order to legitimate forced labor, thus justifying the racist, colonial political economy. 
relationship within the colonial system resulted in the failure to address another very powerful element that constitutes the coloniality at work in Latin America, namely, the ontological dimension of coloniality (coloniality of Being). Coloniality of Being, as Maldonado-Torres formulates the term following Dussel and Mignolo, indicates the insuperable ontological breach fracturing the racialized subject.

Fanon's existential account dramatizes very well the powerful ways coloniality is experienced at the somatic level of the racialized subject. For Fanon, coloniality refers to the rejection of being, thus, the failure of the very category of ontology as life for the native and colonized other "is already a living death."16 The basic, fundamental desire, then, is that of recognition, a recognition of his (the black person's) humanity: "All I wanted was to be a man among other men." 17 This is because, in the colonial reality, "the black man is not a man." ${ }^{8}$ The existential impasse of the black person lies, for Fanon, in the very fact that his existence unfolds upon the "zone of nonbeing," a state of perpetual curse. ${ }^{19}$ It points to the fractured subject who cries for recognition, yet denied, fixed under the white gaze, and "hated, despised, detested, not only by the neighbor across the street... but by an entire race."20

What is more important is that coloniality, however existential, is not a power system that works only upon the psychic edifice of the individual. Rather, it is a mark inscribed in the collective consciousness. Therefore, the most urging task of the writer in the postcolonial or post-plantation era from the $\mathrm{Ca}$ ribbean context is to reinvent a language or discourse for the

16 Nigel Gibson, Fanon: The Postcolonial Imagination (Cambridge: Polity Press, 2003), 14.

17 Franz Fanon, Black Skin, White Masks (New York: Grove Press, 1967), 112.

18 Ibid., 8.

19 Ibid.

20 Ibid., 118. 


\section{SIWÔ ${ }^{\prime}$ volumen 10, Nuimerers 1,2016}

collective identity which entails negotiating the irremediable relation between the traumatic past haunting the collective consciousness and the present marked by discontinuity, the ongoing reality of neocolonialism, and the failure of language.

Theorizing the middle passage is important not only because the experience of middle passage constitutes the matrix of Caribbean historical reality but also because the critique of coloniality needs to start from its very womb. As Dussel, Quijano, and Mignolo suggest, the imperial system of colonial expansion is rooted in a genealogy much longer than the European expansion of the nineteenth century as suggested by postcolonial theory. Rather, according to the Latin American decolonial thinkers, coloniality dates back to 1492 , to Europe's encounter or invention of the "new world."21 In other words, it is not the case that coloniality emerged as the result of modernity. Rather, the birth of modernity needs to be seen as the result of the colonization of the Americas. ${ }^{22}$ Most importantly, as both Quijano and the world system theorists argue, the origin of the modern world system can be attributed to the emergence of the Atlantic commercial circuit in the process of the colonization of the Americas. ${ }^{23}$ In other words, the inception of modernity was made possible because of the middle passage, that is, the trans-Atlantic commercial route through which both the slave trade and the transportation of the material good to Europe took place. This is why, I contend, the trope of exile is highly important and relevant for rethinking liberation theology in the

21 Enrique Dussel, Mabel Moranifa, and Carlos Jauregui. Coloniality at Large: Latin America and the Postcolonial Debate (Durham: Duke University Press, 2008), 5-8.

22 Arturo Escobar, Mas Allá del Tercer Mundo: Globalización y Diferencia (Bogotá: Instituto Colombiano de Antropología e Historia, 2005), 71; Eduardo Mendieta, Latin American Philosophy: Currents, Issues, Debates (Bloomington: Indiana University Press, 2003), 85.

23 Walter Mignolo, "Geopolitics of Knowledge and Colonial Difference." The South Atlantic Quarterly, Vol 101, no 1 (Winter 2002): 60. 
age of neocolonial globalization as exile situates the critique of coloniality at its very historical origin (the middle passage).

Relocating exile in the middle passage allows us, on the one hand, to ground the critique of coloniality not only in its historical root, but also the historical reality conditioning the socio-cultural reality of the Antilles. The trope of exile, then, is neither a romanticization of the devastating experience of displacement nor a decontextualized literary practice. Rather, it is a vigilant critique of the ongoing power relation shaping the lives of many people in Latin America and the Caribbean. On the other hand, the trope of exile constantly evokes the traumatic history of colonialism tainted by the atrocious events of transportation, mass deaths, plantation, violence, and appropriation. This means that exile helps us turn to the inner site of wound and trauma in search of liberation, if not future. Rather than seeking for transformation from a transcendent outside, a radical change irrupting from the outside, the trope of exile allows us to build the counter-colonial account of liberation upon the unfathomable abyss of suffering, by theorizing it and relocating the new beginning, in its open wound. Perhaps, this is why for the decolonial thinkers colonial difference refers to both the irreversible fissure marking the socio-ontological texture of the colonial reality and the very mark of alterity, the site of the birth of decolonial thought, at the same time. Similarly, exile bears dual meaning as it points to the painful historical reality of violent displacement, while at the same time, signaling the possibility of radical critique and transformation. It is then in the work of Edouard Glissant where we find the endeavor of re-conceptualizing the fractured self, the shattered figure of collective identity emerging from the history of trauma and loss as the condition of possibility, and of future. Just as he re-conceives the oceanic abyss of suffering as the "womb abyss" that gives birth to a new collective identity after trauma, Glissant finds in the figure of 


\section{SIWÔ ' volumen 10, Números 1, 2016}

exile -- a reference to the excruciating groundless of being - the genesis of a new mode of thinking and inhabiting the creolized landscape passionately, in infinite solitude and illimitable solidarity, at the same time.

\section{Solitude and Relation, Rootedness and Errantry}

As I raised the question already, how shall we restructure the relation between the spiritual potential discovered in solitude and the collective discourse for the empowerment of community so that solitude and solidarity are articulated as parts of the same process? Might Glissant shed a light on mediating the gap that lies between the privatizing, individualized practice of exile as a form of critical self-reflection and the potential it offers for a collective vision of liberation and transformation?

The beginning point of Glissant's counter-colonial poetic is the "nonhistory" characterizing the history of the Antilles. By this, Glissant is referring to a history of people whose very birth was given by a violent rupture, a traumatic experience of dislocation, deportation, mass deaths, and most importantly, oblivion. Glissant thus places the horror of the middle passage at the center of his poetic and philosophical imagination. However, Glissant does not propose a regressive, melancholic project of mourning the past without bearing an accountable perspective toward the emerging future. Rather, he aims at articulating the paradoxical moment in which the experience of catastrophe and middle passage gives birth to a people. Therefore, Glissant finds in the bottom of the oceanic abyss the emergence of a knowledge that signals "the bigger whole," that is the fabric of relationality that liberates being from its static terms of fixity or essence. "Relation," in the historical experience of the Antilles, does not emerge from nothing. Rather, it emerges 
from the shared experience of suffering. Living in exile, in this sense, bears a strong affinity with living in Relation, for living in exile, as does Glissant's own poetic practice, points to both the figurative and literal practice of embodying the landscape of the archipelago. What we witness in Glissant's poetic is the emergence of a threshold that forms along the fuzzy lines that draw the shorelines of the repeating islands. As Michael Dash writes, the central image for Glissant is neither the sea, nor the land, but "the mediating threshold." 24 The unreckonable wound of the colonial abyss then cracks open on the blurry horizon of the Caribbean shorelines where the sea is not just an indication of the limits of land and history. Rather, the decolonial imaginary of Caribbean thought conceives the sea as the continuation of land and its history.

Likewise, neither the geography nor the identity of the Caribbean people can be determined by the cartographic confines that separate the islands from the sea, for, as the Saint Lucian poet Derek Walcott writes, "there is a territory wider than this - wider than the limits made by the map of an island - which is the illimitable sea and what it remembers." 25 Glissant's poetic is living this experience of paradox or contradiction passionately. Decolonial poetic and the experience of living in exile share a common trajectory in Glissant for they both seek for a new center of gravity, of a new and liberating mode of knowing/being at the convergence of contradicting terms. They envision the one in the multiple, the multiple in one, the mode of being here and elsewhere, "rooted and open, lost in the mountains and free beneath the sea, in harmony and in errantry." 26

24 Michael Dash, Edouard Glissant (Cambridge: Cambridge University Press, 1995), 35.

25 Derek Walcott, The Antilles: Fragments of Epic Memory (New York: Farrar Straus \& Giroux, 1993), 32.

26 Edouard Glissant, Poetics of Relation, translated by Betsy Wing. (Ann Arbor: University of Michigan Press, 1997), 34. 


\section{SIWÔ ${ }^{\text {volumen 10, Nimerers 1, 2016 }}$}

However, envisioning such terms is not confined to a poetic errantry. Rather, Glissant's poetic is "a search for reference," a reference to a new mode of being that finds expression in relation and becoming, a new form of identity in which the individual self finds her rootedness in the collective vision of identity. What does it then mean to live in contradiction, to embody the paradox of beginning in failure or failure in beginning, here and elsewhere, rootedness and errantry, one and multiple? How does one live in solitude and relation (or solidarity) at the same time? As Ellis remarks, living in exile implies living with or embodying contradiction within oneself. In the same way, the meaning of creolized existence Glissant reinvents also indicates a mode of being that not only embraces contradiction but whose very condition of existence is born out of contradiction.

Life in the Antilles is precisely indicative of such contradiction. Despite violence and trauma, despite the horror of death and the haunting memory of the middle passage, life goes on Time persists after trauma; even without a name (the drowning bodies buried under the Atlantic ocean is a reference to both the "loss of name(s)" and "lack of name" to refer to the horrifying event), with no recollection of the self, the traumatic history of suffering still gives birth to future. Before the irrevocable gap lying between the unnamable event of trauma and the urgency to name the unnamable, between the haunting past and the impossible future, Glissant turns to the notion of persistence, the indestructible continuity of time, that is, duration.

Duration refers to the persistence of time, the endurance of life that survives death and goes on after catastrophe. Duration does not connote any sign of ambition or hope. Yet, as its literal meaning indicates, it is that which endures and persists. This is one of the reasons why the tragically sad landscape of the Caribbean islands and the history that accompanies it is, at the 
same time, beautiful. Despite pain, life marked with the ruins of fragmentation endures, survives, and inaugurates future, melancholic or otherwise.

Duration is not, however, an abstract term. It is neither an individual experience nor an apolitical notion. Duration is the very soil from which the "freeing knowledge of Relation within the Whole" arises. Glissant writes, "Duration is share. It is the house of the We..."27 Duration opens the door to relation, and it is only when the self is submitted to the power of Relation that the possibility of future beckons. The enigmatic power of Relation emerges with the knowledge that survives the horror of the middle passage: a knowledge that is born out of the "womb abyss," a "knowledge of the Whole, greater for having been at the abyss and freeing knowledge of Relation within the Whole."28

The middle passage, however traumatic, gives birth to people. Relation is this greater knowledge that survives the horrifying experience of terror, people who were borne by the painful abyss of the middle passage, born into the shore and "rose up on this unexpected, dumbfounded land." ${ }^{29}$ It is in this way that the withdrawal to the inner self, reflecting on the existential torment of living along the threshold of the stupefying and unjust reality, full of contradictions, straddling pain and beauty, between the sea and the land, opens the door to relation. If, for Glissant, death and suffering inaugurates life and community, solitude paves the way for solidarity. The absolute unspeakability of trauma that drives the self to the inner-existential solitude, reveals, at the same time, the other to be the sign of survival. In other words, the other is the sign of the persistence of time

27 Edouard Glissant, Poetic Intention, translated by Nathalie Stephens. (Callicoon: Nightboat, 1997), 201.

28 Glissant, Poetics of Relation, 8.

29 Ibid., 7. 
that carries life on, and which nonetheless gives birth to people, after trauma, just as the drown names (and bodies) mark the "site of multiple converging paths" of connection and relation across the abyss of the dark Atlantic. ${ }^{30}$

The profundity and the excessiveness of the Caribbean landscape that bears witness to its atrocious history of violence and contradiction testifies that the only mode of survival is to create a new, creolized mode of existence, a way of inhabiting the world differently. Since his desire to find rootedness is rejected, he retreats to the inner self and there, in the infinitely sinking solitude, he finds a new center of creolized freedom, a wider (or deeper) sense of rootedness. The sense of rootedness and ground that Glissant searches in his relentless mode of living in exile points to a root grounded in the trace of the other. It is, therefore, a passion. Passion for the other and for the creolized existence that discovers power in the fragments of the impaired present, in the gaping scars molding the cracking heirlooms of the cultural imagination of the Antilles. Passion for exile, a form of life that rejects the cartographic constraints and the hierarchical cosmology imposed by the colonial logic: "... for exile did not arise yesterday: it began with the departure of first caravel. It is not a state, but a passion. ${ }^{31}$ And this is where the powerful paradox of Glissant's decolonial philosophy of creolization lies: passion for rootlessness, groundlessness or solitude, driven by an even greater passion for a deeper sense of rootedness grounded in Relation. He cites the French poet Paul Claudel's words, "from the steps of exile, he manages a solitude more populated than any empire's land." 32

30 Edouard Glissant, Caribbean Discourse: Selected Essay, translated by Michael Dash (Charlottesville: University of Virginia Press, 1989), 66.

31 Glissant, Poetic Intention, 106.

32 Ibid., 108. 
On the other hand, the other as the sign of survival reveals itself only in the unknown. The absolute name of the Other reverberates in the cry filling the time of uncertainty as we are "trembling with the enormous privilege of our limited knowledge." ${ }^{33}$ We are undone as we lose ourselves in the absolute alterity and inexhaustibility of the Other. Both and self and the Other remain nameless. Only one thing remains clear in the unfathomable ocean of the unknown in which the sovereignty of both the self and the other is dissolved: Relation.

\section{Living the Landscape Passionately}

Glissant's poetic of relation also finds a deep resonance in the theological language of Marc Ellis. In articulating the complex dynamic and balance involved in the relation between exile as a process of displacement and diaspora as the emergence of a community after displacement, Ellis suggests "the practice of exile to the point where it becomes a discipline." 34 Keenly aware of the tormenting reality of displaced communities of the global world, Ellis's proposal by no means aim at a romanticized ideal of perpetuating the experience of exile as a liberating practice. Rather, wary of the potential danger lurking in the process of immersing into the individual's solitary practice of exile, the danger of the moment when "speaking the truth to power become[s] one's vehicle of assimilation to power," Ellis proposes that the practice of exile rests on a fine balance of dialectic between solitude and solidarity. ${ }^{35}$

In many ways, Ellis's idea of exile bears an odd, yet similar parallel to Glissant's poetic of creolization. Common to both

33 Ibid., 44.

34 Ellis, Practising Exile, 297.

35 Ibid., 293. 


\section{SIWÔ ${ }_{\text {volumen 10, Nuimeros 1, } 2016}$}

thinkers is notion of an incessant movement of becoming and oscillating between the opposites. The goal of such relentlessness is not to reconcile or remedy the gap separating the two poles. Rather, for both thinkers, the two contradicting terms reveal themselves to be a part of each other. Ellis writes, "for there is no way out of this dialectic of solitude and solidarity... in exile one realizes that solidarity itself forces another level of solitude, and aloneness that is never overcome but becomes an avenue for introspection and love." ${ }^{36}$ In other words, solitude and solidarity are two sides of the same coin that work as complementary terms for each other since solidarity needs to grounded in a spiritual practice of self-scrutiny and self-transformation, while solitude needs to be extended to the political gestures of solidarity with others, particularly, the disenfranchised ones, Ellis adds.

The practice of exile, walking with the public and private aloneness which is part of the struggle to be faithful in our time, must be balanced with a sense of solidarity with those on the other side... in solitude, a person needs to grapple with who he or she is, to become more deeply aware of the commitments and complexities of one's own being.

On the other hand, Glissant's counter-colonial vision of creolization emerges out of the complexity of colonial difference. Its multiply-layered substratum cracks open the historical wound which reveals the fractured self that survived the horrifying trauma. The paradox: the profound solitude found in radical self-reflection reveals the self to be a part of the grater whole, namely, Relation. What Relation reveals, then, is not just the self's connection to the other, but the incomplete nature of the self when disengaged from the other. As the other reveals the immeasurable terms of our fragility and brokenness, we find the sign of hope in this other whom we are able to glance only in

36 Ibid., 299. 
absolute solitude, only when surrendered to the silence or murmur beating in the muted cry before the sea. The excess of the Archipielago's landscape and the contradicting lack of language to speak of its historical reality, reflects the painful texture of colonial reality, which, at the same time, is beautiful.

Duration is not a reference to hope. One finds in it, neither an ambition to transcend the painful complexity of the present nor the will to "grasp" the other. Rather, just like the patience of the landscape that survived the catastrophe and gave birth to people after trauma, duration refers to the persistence of time and the resilience of people who have survived the atrocities of colonial violence and neocolonial socio-economic order. It points to the tireless work of gathering the shards of the shattered fragments, lost memories, and defiled language. Duration is the alluvium for the journey of the self living in exile.

For Glissant, exile gestures neither towards the full reconciliation of the irremediably-split self nor the resignation before such immeasurable gap. The self is split before it begins and the other eludes before signification takes place; the self, so too God, fails in her attempt to found a static ontological ground of being. This is why, perhaps, exile evokes the figurative image of the groundless being floating upon the surface of the bottomless ocean. The self in exile is rootless, groundless, yet she is wholly grounded in her inner ground, in her own gravity of the enduring/creolized self: a self who finds herself as a part of the greater whole, namely, in Relation and solidarity. Therefore, the state of being uprooted is neither a mere reflection of the collective historical reality nor a simple political choice. Rather, it is a strategy of survival. Glissant shows us how to affirm both pain and beauty at the same time. However, he is by no means suggesting the glorification of the reality of suffering. Neither endless mourning nor an ambition of transcendence, Glissant's gesture signals 


\section{STWÔ ’ Volumen 10, Números 1, 2016}

an attitude of hoping without hope, loving by letting it go, and being rooted in the constant movement of becoming.

Nevertheless, despite its elusive and inscrutable nature, exile in Glissant's decolonial imagination is lived with passion, for, the self's absolute solitude is yet another name for the nameless other to whom the "I" is tied to: "although you are alone in this suffering, you share in the unknown with others whom you have yet to know." ${ }^{37}$ Passion for the other is not indicative of a desire to fully grasp the other. Neither does it signify a mere lack of hope. In many ways, Glissant's poetics bears striking resonance with the medieval tradition of negative theology. Both the name of God in negative theology and the name of the other in Glissant's writings remain as the reference beyond the referent, as the sign of inexhaustible alterity lying beyond the name. Beyond its given appearance, the other signals an alterity that eludes our totalitarian attempt while invoking an unending passion for the other in us at the same time. Glissant's philosophy of creolization is an ethical call that makes us to gravitate towards "being oneself to be the other, forever and without hope." 38 In other words, one opens toward the other not by giving up herself, but by fully becoming herself. Thus, being oneself is equated with being "for the other." On the other hand, the contradicting juxtaposition of "forever" and "without hope" might be understood as evoking passion (forever) for the evanescent truth that disappears at the moment one grasps it (without hope), which, perhaps, mirrors the state of living in exile.

37 Glissant, Poetics of Relation, 6.

38 Glissant, Poetic Intention, 201. 


\section{Concluding Remarks}

Thinking (liberation) theology in exile from the context of Latin America and the Caribbean requires a careful scrutiny of the matrix of coloniality conditioning the socio-political surface of the community emerging from the other side of history. A theology of exile bears the potential for a vigilant critique of coloniality as it relentlessly evokes both the history and the present reality of colonial oppression marked with exploitation, appropriation, racialization, and violence. Moreover, a theology of exile, when thinking with Glissant, may also open the door for further developing the rich soil of black spirituality that emerges from the memory of middle passage as the possible resource for resistance and liberation.

The trope of exile might serve as the foundation for liberation theology in the era of neocolonial globalization as it provides a new center of gravity that is accountable to the fragmented experience of people living in exile, fractured by multiplicity, becoming, solitude, and relation (solidarity). Perhaps, what both the unnamable name of God and the unnamable suffering of people who live under colonial violence share in common is that they evoke in us the passion for the impossible and the unnamable, by making us break from the myth of static identity and challenge the socio-political order that forces people into exile from their ground. And it is in such passion that we, too, are driven into exile: exile from the traditional theological discourse; exile from the idea of God as one, unchanging, and transcendent; exile from the binary that separates solitude from solidarity. At the juncture of passion and exile, solitude and solidarity, liberation theology will perhaps find God in exile: a theology in exile and a God in exile, who is, at the same time, our eternal ground. 


\section{Works Cited}

Carew, Jan. "The Caribbean Writer and Exile," Journal of Black Studies, Vol 8, No 4 (Jun 1978).

Dash, Michael. "Engagement, Errance, and Exile," Callaloo, Vol 15, No 3 (Summer, 1992).

. Edouard Glissant. Cambridge: Cambridge University Press, 1995.

Enrique Dussel, Mabel Moranifa, and Carlos Jauregui. Coloniality at Large: Latin America and the Postcolonial Debate. Durham: Duke University Press, 2008.

Ellis, Marc H. "Practising Exile: A Refleciton on the Jewish Exile and the New Diaspora," Swedish Missiological Themes, 85, 3-4 (1997 Escobar, Arturo. Mas Allá del Tercer Mundo: Globalización y Diferencia. Bogotá: Instituto Colombiano de Antropología e Historia, 2005.

Fanon, Franz. Black Skin, White Masks. New York: Grove Press, 1967.

Gibson, Nigel. Fanon: The Postcolonial Imagination. Cambridge: Polity Press, 2003.

Glissant, Edouard Caribbean Discourse: Selected Essay, translated by Michael Dash. Charlottesville: University of Virginia Press, 1989.

- Poetic Intention, translated by Nathalie Stephens. Callicoon: Nightboat, 1997.

. Poetics of Relation, translated by Betsy Wing. Ann Arbor: University of Michigan Press, 1997.

Lahens, Yanick. "Exile: Between Writing and Place," Callaloo, Vol 15, No 3 (Summer, 1992).

Maldonado-Torres, Nelson. "Liberation Theology and the Search for the Lost Paradigm: From Radical Orthodoxy to Radical Diversality," in Latin American Liberation 
Theology: The Next Generation, ed. Ivan Petrella. Maryknoll: Orbis, 2005.

. "On the Coloniality of Being: Contributions to the Development of a Concept." Cultural Studies Vol 21, Nos. 2-3, (March/May 2007):240-270.

Mendieta, Eduardo. Latin American Philosophy: Currents, Issues, Debates. Bloomington: Indiana University Press, 2003.

Mignolo, Walter. "Geopolitics of Knowledge and Colonial Difference." The South Atlantic Quarterly, Vol 101, no 1 (Winter 2002):60

Said, Edward W. Reflections on Exiles and Other Essay. Cambridge: Harvard University Press, 2002.

Walcott, Derek. The Antilles: Fragments of Epic Memory. New York: Farrar Straus \& Giroux, 1993. 